\title{
Petrarca De remediis utriusque fortunaejának recepciója a 16-18. századi magyarországi irodalomban
}

A De remediis utriusque fortunae (más néven: Fortuna-könyv) Petrarca legterjedelmesebb müve, mely nagyjából 1353 és 1366 között keletkezett. ${ }^{1}$ Címe egyértelmủen megjelöli a könyv témáját (utraque fortuna: a jószerencse és a balszerencse), és utal annak jellegére, müfajára („orvosságoskönyv”). Az író keresztény-sztoikus világképében kitüntetett szerepe van a Szerencsének, annak a nagy hatalommal bíró, kiszámíthatatlan erönek, mely az ember életének alakulásáért felelős, amennyiben előidézője az élet egymást követő, kedvező vagy kedvezőtlen fordulatainak. Petrarca fó célja, hogy támogatást nyújtson olvasójának a Szerencsével vívott harcban, vagyis olyan bölcsességekkel szolgáljon, melyek megerösítik annak lelkét, s így könnyebben viseli sorsának hirtelen változásait. A De remediis valóságos enciklopédia, mindentudó kézikönyv, a szerző az első könyv 122 fejezetében a jó-, a második 131 fejezetében a balszerencse orvosságait tárgyalja.

A dialogikus szerkezetü mü szereplöi, a beszélgető felek allegorikus alakok (Ratio, Gaudium, Spes, Dolor, Metus). Petrarca írásának gondolati hátterében a sztoikus filozófia tézisei állnak: nagy hangsúlyt kap az az elgondolás, miszerint az embernek minden körülmények között elsősorban lelki békéje megteremtésére kell törekednie. A világ minden elemének, a benne tapasztalható eseményeknek, történéseknek értéke viszonylagos: azokról, melyeket a közvélekedés jónak ítél, kiderülhet, hogy mulandóak, ingatagok, ártalmasak; azokról, melyeket rossznak, kiderülhet, hogy megedzik, megnemesítik a lelket. Az ember feladata nem más, mint hogy függetlenítse magát a földi dolgok viszonylagosságától, ne engedje, hogy lelkét indulatok, szenvedélyek kavarják fel, értelmére támaszkodva álljon ellen azok támadásának, mert csak így élhet az erénynek megfelelően, s találhatja meg az utat a belső nyugalomhoz, azaz Istenhez. Petrarca mondanivalójának hangsúlyos része, hogy az ember - bár ki van szolgáltatva egy rajta kívül álló hatalomnak, a Szerencsének - alakíthatja saját sorsát, megteremtheti lelki egyensúlyát, ha elfogadja, hogy az egyetlen valódi érték a krisztusi értelemben vett evilági jóság és az annak révén elnyerhető mennyei boldogság.

Fontos tudni, hogy a De remediis hosszú időn keresztül (a Daloskönyvet nem számítva) az író legnépszerűbb, legolvasottabb könyve volt: a 15-18. század között több mint harminc (önálló vagy gyüjteményes) kiadást ért meg. Nyomtatott formában történt terjedésének két fő központja - mind fordításban, mind eredetiben - a mai Né-

\footnotetext{
${ }^{1}$ A mű eddigi legteljesebb magyar nyelvű bemutatását további szakirodalommal lásd Lengrel Réka, Petrarca, a lélekvezető: A De remediis utriusque fortunae átfogó bemutatása, Szeged, 2012 (doktori diszszertáció). http://doktori.bibl.u-szeged.hu/1592/ (Letöltés ideje: 2014. január 30.)
} 
metország déli része és Svájc, valamint Párizs volt, ami érthető következménye annak, hogy a mü kéziratai is e területeken voltak a legnagyobb számban megtalálhatóak. Azt is megállapíthatjuk, hogy Petrarca írása a 17. század második feléig folyamatosan jelen volt az európai könyvpiacon, a mindenkori olvasóközönség igényeihez igazodó példányszámban. Ezek a kötetek, föként a latin nyelvüek, magyar olvasókra is találtak, s a De remediis-kultusz legkésőbbi fejezete éppen a 18. század folyamán hazánk területén megjelent kiadványok történeteként írható le. A mü 16-19. századi magyarországi recepciójáról Turóczi-Trostler József, Máté Ágnes és Szörényi László átfogó jellegü tanulmányai részletes felvilágosítást adnak; ${ }^{2}$ kutatási eredményeik összegzésétől mindazonáltal nem tekintek el abból a megfontolásból, hogy az elszórt adatok együvé gyüjtve áttekinthetőbbek legyenek, és mert néhány esetben pontosítással és kiegészítésekkel is szolgálhatok.

Petrarca latin és olasz nyelvű müveinek ismerete a magyar írók, költők körében az 1500-as évek elejétől adatolható: olvasták, idézték, fordították szonettjeit és a Triumphi sorait (például Brodarics István, Balassi, Zrínyi és a Constantinus és Victoria-dráma szerzője); magyar fordítása készült a Petrarca által latin változatban terjesztett Boccaccio-novellának, a Griseldának (Istvánfi Pál verses históriája); továbbá biztosan eljutottak hazánkba verses levelei (a Fejedelmeknek serkentő órája egyik versbetéte az Epistolae metricae 34. darabjának két sora), valamint a Sine nomine levélgyüjtemény, a Secretum és a De vita solitaria. ${ }^{3}$ Olvasta Petrarcát Rimay is, aki az antik sztoikus filozófusokkal egy sorban említi. ${ }^{4}$ Könnyen lehet, hogy a Petrarcával „beszélgeto”" Rimay éppen a dialogikus felépítésű De remediis olvasására célzott, hiszen több adat is utal arra, hogy a művet nálunk is ismerték, s olykor kölcsön is vették belőle Petrarca gondolatait.

Az egyik jellemző hivatkozásra Pázmány Péter prédikációjában találhatunk rá, aki a Mint kell a keresztény leányt nevelni címü beszédében a tánc ártalmas voltára kitérve a Fortuna-könyv I. 24. dialógusából idéz. ${ }^{5}$ Egy másik 17. századi szerzőnk, Miskolci Csulyak István könyvjegyzékén a Secretum és a De vita solitaria mellett a De remediis is szerepel, s önéletírásából tudjuk, hogy szerettei elvesztésének fájdalmát Seneca,

\footnotetext{
${ }^{2}$ Turóczi-Trostler József, Keresztény Seneca, EPhK, 1937/1-3, 25-75; Máté Ágnes, Francesco Petrarca De remediis utriusque fortunae $c$. müvének 18. századi magyar változatai = Varietas Gentium - Communis Latinitatis: A XIII. Neolatin Világkongresszus (2006) szegedi előadásai, szerk. SzÖRÉNYI László, LÁzÁr István Dávid, Szeged, JATEPress, 2008, 59-68; SzÖRÉNYI László, Petrarca eszmetörténeti hatása a XVI-XVII. századi magyar irodalomban = Sz. L., Önfiloszhattyú: Irodalomtörténeti rejtélyek, Bp., Balassi, 2010, 52-66. ${ }^{3}$ Vö. SZÖRÉNYI, $i . m$., 54-58, 60-62.

${ }^{4}$ „[A]z philosophiának usussához, és nem az felőle való csacsogáshoz szabván életemet, Seneccával, Petrarchával, Ciceróval és Epictetussal beszélgetek többet, hogy nem egyeb emberekkel.” Idézi BiTsKeY István, Egy Rimay-vers világa = B. I., Eszmék, müvek, hagyományok: Tanulmányok a magyar reneszánsz és barokk irodalomról, Debrecen, Kossuth Egyetemi Kiadó, 1996, 94.

${ }^{5}$ Lásd SzÖRÉNYI, i. m., 58. Szörényi arra is kitér, hogy Petrarcát pápaellenes írásai miatt előszeretettel idézték a református teológusok. Pázmány azonban a Feleletben amellett érvel, hogy a pápákat érintő kritikus megjegyzései ellenére Petrarca igazi katolikus volt. (Szörényi hivatkozása: Pázmány Péter, Felelet az Magyari István sárvári praedicatornak az Ország romlása okairul irt könyvére = PÁzMány Péter Összes Munkái, s. a. r. RapaICs Rajmond, I, Bp., M. Kir. Tud.-Egyetemi Nyomda, 1894, 29, 33, 61.)
} 
Plutarkhosz és Petrarca műveivel orvosolta. ${ }^{6}$ (A De remediis második könyvében külön csoportot alkotnak a családtagok elvesztéséről szóló dialógusok.) A következő utalás Szilágyi Tönkő Márton Biga pastoralis, seu ars orandi et concionandi címü, 1684-ben Debrecenben megjelent prédikációs kézikönyvében olvasható. Érdemes részben idézni fejtegetéseit az igazi keresztény filozófiáról, melynek szerinte a Szentírás lábnyomát kell követnie: „ut Franciscus Petrarcha, in libello suo elegantissimo: De ignorantia sui et aliorum loquitur, non fallacibus alis attollitur et sterilium disputationum ventosa iactanctia per inane circumvolvitur; sed quae certis et modestis gradibus compendio ad rerum ac Dei notitiam perducit."’ Az idézett gondolat valóban Petrarcától származik, Szilágyi Tönkő azonban rosszul emlékezett, vagy rossz címet jegyzett fel hozzá, ez a mondat ugyanis nem a De ignorantiában, hanem a Fortuna-könyv I. könyvének elöszavában olvasható. ${ }^{8}$

Nehéz megállapítani, mely kiadásokat használhattak az eddig említett szerzők a $D e$ remediisnek a 16-17. században megjelent változatai közül. Noha már a 18. század magyar irodalmi termésének részét képezi, röviden itt szólok Székely László9 $1760-62$-ben keletkezett teljes magyar fordításáról, mert ennek alapjául is a mü egy jóval korábbi kiadása, az 1613-as genfi szolgált. ${ }^{10}$ Az 1290 lapnyi, Magyar Petrarcha címü fordítás kéziratban maradt, a székelyudvarhelyi Haáz Rezső Tudományos Könyvtár őrzi a fordító saját kis kötetével, mely az 1613-as kiadás egy példánya. Nem tudjuk, honnan került e könyv Székelyhez, más kéz nyoma nem található benne, csak a gróf bejegyzései, aki

\footnotetext{
${ }^{6}$ SZÖRÉNYI, i. m., 59-60.

${ }^{7}$ SzILÁgy TönKő Márton, Biga pastoralis, seu ars orandi et concionandi, Debrecen, Töltesi István, 1684 (RMK II, 1536), 107. Idézi SzÖRÉNYI, i. m., 63-64.

8 „Hec est enim vera philosophia, non que fallacibus alis attollitur et sterilium disputationum ventosa iactanctia per inane circumvolvitur, sed que certis et modestis gradibus compendio ad salutem pergit." De rem. I, Elöszó, 5. Az Előszó teljes szövegét lásd Lengyel Réka, Részlet Francesco Petrarca De remediis utriusque fortunae-jából [Elöszó] = „Nem sülyed az emberiség!”... Album amicorum Szörényi László LX. születésnapjára, szerk. Jankovics József, Csörsz Rumen István, CsászTvaY Tünde, Szabó G. Zoltán, Bp., MTA Irodalomtudományi Intézet, 2007, 169-183. - Ahogyan az összevetésből kitűnik, a debreceni prédikátor megváltoztatta a mondat befejezését.

${ }^{9}$ Székely László (1716-1772) alamori gróf, tanulmányait Nagyenyeden és Nagyszebenben végezte. Irodalmi munkásságának nagy részét fordítások teszik ki, de igen értékes verses önéletrajza is. Életét és az Önéletírás szövegközlését lásd NÉMETH S. Katalin, Székely László verses önéletírása, Lymbus, 2006, 44-98; Székely könyvtáráról lásd JA Kó Zsigmond, A székelyudvarhelyi tudományos könyvtár története = J. Zs., Irás, könyv, értelmiség, Bukarest, Kriterion, 1976, 219-251.

${ }^{10}$ Székely László fordítását a kézirat lelőhelyén, Székelyudvarhelyen Máté Ágnes vizsgálta meg alaposan, s a kutatás eredményeit 2007-ben készült szakdolgozatában foglalta össze (MÁTÉ Ágnes, Francesco Petrarca De remediis utriusque fortunae c. müvének 18. századi magyar változatai, Szakdolgozat, SZTE BTK, 2007, kézirat). Ezúton is köszönöm neki, hogy a kéziratot a rendelkezésemre bocsátotta. (A kéziratot és a Székely-könyveket nem ismerő Németh S. Katalin még nem tudta megállapítani, Székelynek melyik Petrarca-kiadás volt meg. Lásd erről NémeTH S. Katalin, „Petrárchának ezen jeles szavai”: Székely László Petrarca-fordítása = „Nem sülyed az emberiség!”, i. m., 193.) - Fiske szerint a De remediis 1613-ban Bernben jelent meg, az 1595-ös kiadás ötödik utánnyomásaként. (D. Willard Fiske, Francis Petrarch’s treatise De remediis utriusque fortunae: Text and versions, Firenze, Le Monnier, 1888, 8.) Könyvtári katalógusokban kiadási helyként mind Bernt, mind Genfet megtaláljuk.
} 
gondosan kijavította a sajtóhibákat, s aláhúzással emelte ki a számára különösen kedves vagy elgondolkodtató sorokat. ${ }^{11}$ Biztosra vehetjük, hogy a De remediis Székely meghatározó olvasmányai közé tartozott, 1763-ra datálható verses Önéletírásának bevezetőjében ugyanis tíz lap terjedelemben átvesz több részletet a Petrarca-szövegböl..$^{12} \mathrm{Az}$ önéletrajz bevezetőjébe került De remediis-részletek azért is érdekesek, mert Székely nem a kevéssel korábban elkészült fordítását idézi, hanem újrafordítja az eredeti latin szöveget. ${ }^{13} \mathrm{~A}$ Fortuna-könyv magyarra való átültetésével - amint ajánlásában írja - egyrészt az volt a célja, hogy „született nyelvünkön” olvasója hasznát szolgálja, másrészt az, hogy senki ne vádolhassa restséggel. Máté Ágnes Székely életrajzának ismertetése kapcsán arra utal, hogy a grófot ért szerencsétlenségek, veszteségek személyes indíttatásul szolgáltak számára. ${ }^{14}$ Fordítói módszerét Máté így jellemzi: „a latinhoz nagyon közeli magyar szöveget igyekszik létrehozni, és a saját képességeihez mérten egy meglehetősen szoros fordítást készít". ${ }^{15}$ Az így létrejött szöveg, állapítja meg Máté, bővebb mint a latin eredeti: Székely sokszor nem tudott dönteni, melyik magyar szóval adja vissza a latint, ezért magyarázza, értelmezi azt; másutt a történelmi, mitológiai személyek, alakok rövid bemutatását toldja be, de személyes megjegyzéseket is tesz. ${ }^{16}$ Nyelvét, stílusát illetően megállapíthatjuk, hogy a kor irodalmi nyelvének színvonalán mozog, igen kifejező, változatos, gazdag nyelvet mozgósít, mind szóhasználata, mind fogalmazásmódja eredeti: a korabeli erdélyi nyelvállapot rendkívül értékes dokumentuma és forrása - sajnálatos, hogy nyomtatásban sohasem látott napvilágot. ${ }^{17}$ Nyelvi és irodalmi értékei miatt és

\footnotetext{
${ }^{11}$ Könyvészeti leírását közli Máté, Francesco Petrarca (2007), i. m., 25-28.

${ }^{12}$ Hosszú részleteket másol önéletrajzába a II, 5, 6. dialógusokból, melyek fő mondanivalója, hogy nem a nemesi származás teszi naggyá az embert, hanem az egyéni virtus. Németh S. Katalin szerint Székely számára Petrarca üzenete önigazolásul szolgálhatott, családjuk ugyanis önerőből emelkedett nemesi rangra. Lásd NÉMETH S., „Petrárchának ezen jeles szavai”, i. m., 194.

${ }^{13}$ Érdemes idézni ugyanannak a részletnek a kétféle fordítását (Máté Ágnes átírása): „A mint Heraclitus írja; Mindenek Ellenkezésekkel, s Ellenkezések által fóljnak, ez úgj is vagjónn és hógj úgj légjenek, tsak nem mindenek úgj bizónjittják. A Gjórs Tsillagos Éggel, a Tsillagók szemben találkóznak. Az egjmással ellenkező Éltető Állatók egjmással Viaskódnak. A Főld meg reszket. A Tenger habozik, zúg. Az Éltető Ég szűntelen mózgattattatik. Az Tüznek lángja harsóg, zeng. Az Szelek vég nélkủl való zúgást tésznek, mint meg annji hadakózásókat. Az Idők az Időkkel veszekednek. Kủlőn kűlőn mindenek magók magókkal, mi velünk pedig mindenek." (Önéletírás, 3-4.); „...mint Heraclitusnak amaz mondása: Mindenek az azokból származni szokott ellenkezések szerint foljnak, úgj is vagjon, és hogy igj légjen tsaknem mindenek bizonjittják. A tsillagok az tsillagos égen gjorsan szembe találkoznak. Az egjmással ellenkező éltető állatok egjben ütkőznek; A földők meg rendülnek; A Tengerek zugnak haboznak; Az levegő ég ingattatik; Az Lángok ropognak; Az Szelek halhatatlan hadakozást viselnek; Az Idők az Időkkel veszekednek; Mindenek magokkal; Mi velünk mindenek;" (Magyar Petrarcha, 768). Lásd MátÉ, Francesco Petrarca (2007), i. m., 46-48.

${ }^{14}$ Uo., 34 .

${ }^{15}$ Uo., 36-37.

${ }^{16}$ Lásd Uo. - Az I, 111. dialógus címét (De alchimia) így magyarítja: A Metallumokat, ezüstőt s egjebet arannjá változtato Mesterségről. Vagy: A Cerberust tartják a Pokol Kapuján álló 3. Fejü Ebnek. Továbbá: amaz Africai első Scipiorol (kinek nevit tsuda dolog honnét, Gjeremekségemtől fogva szerettem).

${ }^{17}$ A Pinitianus-disztichonokat Székely négysoros, aaaa rímelésű versekben fordítja le. Ezek színvonala
} 
egyediségénél fogva (a De remediis eddig egyetlen teljes magyar fordítása) mindenképpen több figyelmet érdemel a kutatás részéről, $s$ fontos, hogy a magyar olvasók számára is minél hamarabb elérhetö legyen.

Székely fordításával átléptünk a 18. századba, melynek első felében a nagyszombati jezsuita tanárok hatékony müködésének eredményeképpen a magyarországi könyvnyomtatás gyors ütemben behozta elmaradását más európai országokhoz képest: 1706 és 1758 között a De remediis kivonata, fordítása és teljes latin szövege összesen nyolc kiadást ért meg. (Az erdélyi gróf egyébként valószínüleg nem tudott ezekről a könyvekről.)

Turóczi-Trostler József az antik görög és római filozófia európai továbbélését, valamint a sztoicizmus és Seneca recepcióját tárgyaló, pontos és időtálló meglátásokkal tüzdelt, a legszigorúbb tudományossággal megírt, nagy ívü tanulmányában részletesen bemutatja az általa „magyar stoikus nyárutó”-nak nevezett korszak szellemi áramlatait és könyvtermését. ${ }^{18} \mathrm{Az}$ érintett szerzők, teológusok, tanárok „,szinte kivétel nélkül katolikus környezetből kerülnek ki és szinte kivétel nélkül a jezsuita rend tagjai", ${ }^{19}$ központjuk Nagyszombat. „Legmélyebben hatolt a római Stoa szellemébe Rajcsányi György (1669-1734), [...] tájékozódásának két végső pontja: Krisztus és Seneca, az unio mystica és a tranquillitas animae; ugyanaz az út vezet az egyikhez is, a másikhoz is: a lemondás, az Isten akaratával megegyező, fegyelmező kegyes élet."20 Kiadta Cebes Tabula és Epiktétosz Enchiridion című művét; önálló föműve, a Laurus Tuta teológiai írás a keresztény hit alaptételeiről. Öccse, Rajcsányi János hasonló területen tevékenykedett, „magyar és latin nyelvü, a katolikus hitet bemutató munkáiban magyarázta az egyházi tantételeket, $\mathrm{s}$ bírálta a protestáns felekezeteket" (közülük az egyik, az Itinerarium Athei, ad veritatis viam deducti Petrarca Fortuna-könyvéhez jellegében hasonló mü, több filozófiai, vallási tárgyú alapműből szerkesztett kompiláció). ${ }^{21}$ Petrarca De remediise szellemiségében a lehető legközelebb áll a Rajcsányi-testvérek által kedvelt antik filozófusokhoz, egyházatyákhoz, ezért nem meglepő, hogy György ezt a müvet is alkalmasnak gondolta a kiadásra, valószínűleg azért is, mert párbeszédes formája révén az iskolai oktatásban is jól alkalmazhatónak vélte. (Bíró Csilla rámutat, hogy Loyolai Ignác Exercitia Spiritualiájának egyik központi tétele, az indifferencia elmélete rokon a Fortuna-könyv üzenetével. ${ }^{22}$ )

elmarad prózai teljesítményétől, s verses önéletrajzához hasonlóan elmondható róluk, hogy noha kezdetlegességük néhol Tinódit idézi, vannak olyan költői képei, melyek kifinomult ízlésről tanúskodnak. Király Pál megállapítását idézi Máté, Francesco Petrarca (2007), i. m., 41.

${ }^{18}$ Turóczi-Trostler, i. m., 44-72.

${ }^{19}$ Uo., 45.

${ }^{20}$ Uo., 46.

${ }^{21}$ Az Itinerarium Athei 1704-ben jelent meg Bécsben. Egyik fejezete magyarul is olvasható, saját fordításomban, lásd RAJCsáNYI János, Az ateista útikalauza = Magyarországi gondolkodók, 18. század, Bölcsészettudományok I, szerk., utószó TüsKés Gábor, munkatárs LeNGYel Réka, Bp., Kortárs, 2010, 10-18; a vonatkozó jegyzeteket lásd a 808-812. lapokon.

${ }^{22}$ Bíró Csilla, Le due fortune dei gesuiti di Tirnavia: Le edizioni del libro De remediis utriusque Fortunae a Tirnavia = Petrarca e l'unità della cultura europea: Atti del Convegno Internazionale, Warszawa 27-29 maggio 2004, a cura di Monica Febbo, Piotr Salwa, Warszawa, Semper, 2005, 489-496. 
Az 1706-ban kiadott első válogatásba - melyet egy nevét elhallgató társuk az az évben végzős Amadé Lászlónak és évfolyamának ajánlott ${ }^{23}$ - Petrarca írásából összesen negyvenkilenc dialógus került be (az első könyvből 19, a másodikból 30 dialógus), de nem változatlan formában: kiadója sok helyütt egyszerüsített, két-három dialógust egybeolvasztott, megadta a jelöletlen idézetek forrását. ${ }^{24} \mathrm{~A}$ következő évben megjelent újabb válogatás egy jóval bővebb merítés: 28 fejezetet vettek át a De remediis első, 58-at a második könyvéből. A kötetet Pibér László almízi püspöknek ajánló Hunyadi István hangsúlyozta, hogy nemcsak a líceumok és akadémiák hallgatói, hanem a kúriák tagjai is haszonnal forgathatják, nem azért, hogy így szélesítsék müveltségüket, sokkal inkább a lelki épülés céljából. Ezt a második válogatást 1718-ban más címmel és ajánlással (szerzője Farkas Antal, a címzett Malik Ádám nagytapolcai plébános) változatlan tartalommal újra kiadták.

Bíró Csilla szerint, tekintve, hogy a három kiadás egy-egy liber promotionis, és hogy „Rajcsányinak az emberi élet alapkérdéseihez kapcsolódó témaválasztásai, a dialógusok átalakítása, és a könnyen megjegyezhető, tanulságos disztichonok mind-mind didaktikus célokat szolgálnak, ezért joggal feltételezhetjük, hogy Petrarca De remediise, még ha megváltozva is, jelen volt a nagyszombati és a kassai iskolai oktatás mindennapjaiban”. ${ }^{25}$ Bíró azt is megállapítja, hogy egyelöre nem tudjuk, vajon Petrarca dialógusai „csak olvasásra szánt minták voltak-e az előadandó declamatiókhoz, vagy pedig használták őket előadásra is" a nagyszombati diákok nyilvános vitáinak alkalmával. A kérdés megválaszolásához az iskola évkönyveinek, historia domusainak feldolgozása vihet közelebb. ${ }^{26}$

A Rajcsányi-féle 1706-os kiadásnak két különböző fordítása született: László Pálé 1720-ban Kassán, egy ismeretlen magyar nemesé 1813-ban Debrecenben jelent meg. ${ }^{27}$ A váradi kanonok László Pál (meghalt 1729-ben) a kötetet zabolai Mikes Mihály grófnak ajánlotta; művében a Rajcsányitól átvett és lefordított disztichonokat és dialógusokat egy-egy Elmélkedéssel toldotta meg. (Igen érdekes tény, hogy egy, Székely Lászlóhoz korban és „területileg” ennyire közel álló szerző tollából való a De remediis legkorábbi fordítása; egyébiránt semmi nem utal arra, hogy az alamori grófhoz eljutott volna a váradi kanonok munkája.) Nem kell külön hangsúlyoznunk, hogy a Fortuna-könyv első magyarítása "felbecsülhetetlen szellemtörténeti jelentőséggel bír”. ${ }^{28}$

Turóczi-Trostler József már rámutatott arra, hogy amikor László Pál könyve megjelent, „a szépprózát néhány XVI. és XVII. századi »népkönyv«, irodalomalatti trufák, pár »lesüllyedt« meseszerü elbeszélés, aesopusi mese, prédikációkban meghúzódó antik-

\footnotetext{
${ }^{23}$ Lásd Máté, Francesco Petrarca (2007), i. m., 15.

${ }^{24}$ Lásd erről részletesen BíRó, i. m., 492; vö. Máté, Francesco Petrarca (2008), i. m., 60.

${ }^{25}$ Bíró, i. m., 495.

${ }^{26}$ Uo., 496.

${ }^{27}$ A László-féle fordításnak egy 1720-as, Kassán kelt kézirata is fennmaradt (OSzK, Oct. Hung. 22). Vö. Máté, Francesco Petrarca (2007), i. m., 50.

${ }^{28}$ Turóczi-Trostler, i. m., 65.
} 
középkori csökevény” képviselte. Így a fordító a 16-17. századi magyar „renaissancehullám” óta „parlagon heverö" nyelvi elemekkel dolgozott, s a Petrarca klasszikus latin retorikájával vívott „hősies küszködés” eredményeképp müvének vannak olyan részletei, melyeket „bátran Mikes és Faludi prózája mellé állíthatunk”, akiket ráadásul időben jócskán megelőzött. László Pál fordítására is igaz, amit fentebb Székely Lászlóéról elmondtunk: a méltatlanul mellözött és elfeledett írásmüvet egyedülálló értékei prózairodalmunk kiemelkedő darabjává avatják, $\mathrm{s}$ ez mind az olvasók, mind a kutatás részéről nagyobb figyelemre érdemesítené.

Az 1813-as debreceni kiadás szövegéről Jakó Zsigmond korábban - hiányos adatok ismeretében - azt feltételezte, hogy Székely László fordítása lehet. ${ }^{29}$ Máté Ágnesnek köszönhetjük, hogy a két szöveg összehasonlítását elvégezve minden kétséget kizáróan megállapította Jakó feltevésének téves voltát, $s$ rájött arra, hogy az ismeretlen magyar nemes művének, László Páléhoz hasonlóan, az 1706-os válogatott kiadás volt az alapja, noha erre a kötetben semmi sem utal. ${ }^{30} \mathrm{Az}$ ismeretlen szerző valószínűleg nem ismerte László fordítását, attól teljesen függetlenül dolgozott, $s$ „időpontja követelményeinek megfelelően úgyszólván teljesen a nyelvmüvelés és pallérozás szempontja" vezette, ${ }^{31} \mathrm{ol}$ vasói lelki épülését kevésbé tartotta szem elött.

A De remediis kivonatos kiadásainak és fordításainak áttekintése magyarázatul szolgál arra, miért történt, hogy a mü teljes latin szövegét is megjelentették, elöször Budán, 1756-ban, $s$ két évvel később Egerben, változatlan utánnyomásban. ${ }^{32} \mathrm{~A}$ budai kiadás Koroda Teofil doktorrá avatásának alkalmából, gróf Batthyány József költségén, a Landerer-nyomdában jelent meg. Tudjuk, hogy Batthyány a nagyszombati egyetemen tanult, így már fiatalon megismerkedhetett Petrarca művével (akár a Rajcsányi-féle válogatások, akár valamely teljes külföldi kiadás is a kezébe kerülhetett), nem csoda tehát, hogy később, már magas rangú egyházi vezetőként és kora egyik legbőkezűbb mecénásaként hozzájárult ahhoz, hogy a Fortuna-könyv Magyarországon is napvilágot lásson. ${ }^{33}$ Az 1758-as kiadás szintén liber promotionis volt, Trásy János doktorrá avatásakor, gróf Forgách János anyagi támogatásával jelentették meg. ${ }^{34} \mathrm{Ez}$ a két könyv bizonyára sok korabeli föúri, egyházi könyvtárba bekerült, de erre nézve egyelöre nem rendelkezünk elegendő adattal. Valószínű, hogy Androvics Miklós egri kanonok könyvtárában az 1758-as kiadás volt megtalálható. ${ }^{35}$

\footnotetext{
${ }^{29}$ JAKÓ, i. m., 229.

${ }^{30}$ Máté, Francesco Petrarca (2008), i. m., 63-65.

${ }^{31}$ TurócZi-Trostler, i. m., 65.

${ }^{32}$ Vö. Uo., 65; MÁté, Francesco Petrarca (2008), i. m., 65-66.

${ }^{33}$ Lásd Lengyel Réka, La fortuna ungherese del Libro di Fortuna del Petrarca (Le edizioni ungheresi del De remediis utriusque fortunae nel secolo 18), Camoenae Hungaricae, 2006, 170.

${ }^{34}$ Uo., 171.

${ }^{35}$ Vö. BIтskey István, Püspökök, írók, könyvtárak: Egri föpapok irodalmi mecenatúrája a barokk korban, Eger, Heves Megyei Múzeumi Szervezet, 1997, 103. Ezúton is köszönöm Tüskés Gábornak, hogy felhívta a figyelmemet erre az adatra.
} 
A 16-18. századi magyarországi De remediis-recepció történetének bemutatása révén nyilvánvalóvá válik, hogy az elmúlt száz év, s különösen az utóbbi egy-két évtized során számos új adattal gazdagodott a jelenségre vonatkozó tudásunk. Turóczi-Trostler 1937-ben ezt írta: „....az igazi Petrarcának is csak a petrarkizmus (Balassa, Rimay) a petrarkizáló humanisták, a Petrarca nevétől különvált hét bünbánó zsoltár révén van némi köze a magyar irodalommal. Idézni ugyan idézik a nevét, vagy egy-egy mondatát, de rendszerint csak másodkézből, harmadforrásból." ${ }^{36}$ Ehhez képest, ahogyan a fentiekből kiderül, több példa is bizonyítja, hogy a magyar olvasók elsőkézből, a hazánkba eljutott külföldi Petrarca-kiadások útján ismerkedhettek meg az itáliai humanista nevével és müveivel, melyek, köztük a Fortuna-könyv, igazolhatóan kedvelt, szívesen idézett olvasmányává váltak többeknek is, s például Seneca vagy Boethius írásai mellett mind a magánjellegü (Miskolci Csulyak István, Székely László), mind a közösségi célú (Pázmány, Szilágyi Tönkő prédikációs gyakorlata) használatuk kimutatható.

Ahogyan a De remediis európai befogadás- és hatástörténete kapcsán is megállapítható, a magyar olvasók sem elsősorban a Petrarca által olyan nagy mennyiségben „adagolt” antik és keresztény példákra, a humanista s egyben az európai müveltség ismeretanyagára voltak kíváncsiak, sokkal inkább lelki épülésük előmozdítása miatt vették kezükbe a könyvet. Petrarca belső, lelki életük eseményeinek feldolgozásában, megélésében vált segitőjükké, beszélgetőtársukká, bármely élethelyzetre kész válaszokkal, vigasszal szolgáló „pszichológusukká” - ahogyan annak számított a szintén sokat forgatott és fordított Seneca is. Az itáliai szerző „Párbeszédei a platonista és stoikus hullámmal együtt vonulnak be a magyar szellemi életbe - írja Turóczi-Trostler -, az után, hogy bejárták egész Európát." ${ }^{77} \mathrm{~S}$ hazánk szellemi életének, teológiai-filozófiai tájékozódásának alapelemévé váltak, legalábbis ami a 18. századot illeti. Turóczi-Trostler következő meglátása is teljességgel helytálló: „A lelkiélet szükségletei, útjai sokkal ellenőrizhetetlenebbek, rejtélyesebbek, semhogy képesek volnánk felszínes kultúrszociológiai magyarázatokkal megvilágítani őket. Úgy látszik, valami ellenállhatatlan békevágy, lemondás hangulata keríti hatalmába a magyar intellektuális-humanista réteg képviselöit."38 Petrarca De remediise valóban a lelkiélet megélésének alapszövege lett, befogadásának története a magyarországi (s felekezetektől független, jobban mondva azok összességét magában foglaló) lelkiségtörténet egyik fontos fejezete. Ahhoz, hogy erről a fejezetről még pontosabb képet alkothassunk, további kutatások szükségesek, melyek az eddig elvégzett kiadás- és fordítástörténeti jellegü vizsgálatokat a befogadás- és hatástörténet vonatkozásában kiegészítve más jellegű ismeretekkel gazdagítják tudásunkat a Fortunakönyv magyarországi olvasóiról.

\footnotetext{
${ }^{36}$ Thuróczy-Trostler, i. m., 64.

${ }^{37}$ Lásd Uo.

${ }^{38}$ Uo., 44.
} 


\section{RÉKA LENGYEL}

The Reception of Petrarch's De remediis utriusque fortunae in 16-18th century Hungarian literature

In the 14th-18th centuries Petrarch's most widely disseminated work was De remediis utriusque fortunae. Petrarch's Latin works had been known in Hungary since the 15th century and in the 18th century a real cult of De remediis can be traced, proved by the correspondence of contemporary aristocrats, scholars and politicians (e. g. István Brodarics, Farkas Kovacsóczy). His sonnets and the lines of Triumfi were often read, quoted, translated (e. g. by Bálint Balassi, Miklós Zrínyi); the Griselda, Boccaccio’s novel, known mainly in Petrarch's Latin translation, also got translated into Hungarian (by Pál Istvánfi). His letters written in verse, as well as the Sine nomine collection, the Secretum and the De vita solitaria were certainly being read in Hungary. During the 17th-18th centuries Hungarian readers could get acquainted at first-hand with the name and works of the Italian humanist through the foreign printed editions of Petrarch's writings. Writers, scholars, ecclesiastical leaders and others read and used these texts for both private and public purposes. In the 18th century De remediis was reedited eight times and its only complete translation so far was prepared between 1760 and 1762. The reception of De remediis is thus a highly important chapter in Hungarian spiritual history. 